\title{
cGAS-STING: insight on the evolution of a primordial antiviral signaling cassette
}

\author{
Hua Cai ${ }^{1}$ Jean-Luc Imler ${ }^{1,2^{*}}$ \\ ${ }^{1}$ Sino-French Hoffmann Institute, School of Basic Medical Science, Guangzhou Medical University, Guangzhou, China \\ ${ }^{2}$ Université de Strasbourg, CNRS UPR9022, Institut de Biologie Moléculaire et Cellulaire, Strasbourg, France
}

\begin{abstract}
Stimulator of interferon genes (STING) functions in the cytosolic DNA-sensing pathway of innate immunity in mammals. It is activated upon binding the cyclic dinucleotide 2'3'-cGAMP, a second messenger produced by the enzyme cyclic guanosine monophosphate-adenosine monophosphate synthase (cGAS), which acts as the receptor for DNA in this pathway, and triggers the expression of interferons and other viral stress-induced genes. The ancient origin of STING in the evolution of animals had been noted, but its primitive function was speculative. We review here recent advances in the remarkable history of cGAS-STING signaling, which establish that cGAS is a member of the family of cGAS/DncV-like nucleotidyltransferases (CD-NTases). In bacteria, CD-NTases synthesize a wide range of cyclic oligonucleotide second messengers in response to bacteriophage infections, which in turn activate a variety of effector proteins to abort phage infection. Among these effectors, some are related to STING, revealing an ancestral function for the cGAS-STING cassette in antiviral host defense. Study of STING signaling in invertebrate animals is consistent with an early acquisition in the history of metazoans of CD-NTase- and STING-encoding genes to counter the universal threat of viruses. In particular, STING-dependent immunity appears to play a previously unsuspected important role in some insects. These discoveries open up interesting perspectives for the use of model organisms to decipher emerging aspects of cGAS-STING biology in mammals, such as the activation of interferon-independent responses or the function and regulation of cGAS in the nucleus.
\end{abstract}

\section{Keywords}

innate immunity, cGAMP-2’3', cGAMP, CBASS, CD-NTase, interferon

\section{Peer Review}

The peer reviewers who approve this article are:

1. Russell E Vance, Division of Immunology and Pathogenesis, Department of Molecular and Cell Biology, University of California, Berkeley, USA

Shally Margolis, Division of Immunology and Pathogenesis, Department of Molecular and Cell Biology, University of California, Berkeley, USA

Competing interests: No competing interests were disclosed.

2. Ronald van Rij, Department of Medical Microbiology, Radboud Institute for Molecular Life Sciences, Radboud University Medical Center, Nijmegen, The Netherlands

Competing interests: No competing interests were disclosed.

3. Zhijian J Chen, Department of Molecular biology, University of Texas Southwestern Medical Center, Texas, USA Competing interests: No competing interests were disclosed. 
*Corresponding author: Jean-Luc Imler (j1.imler@ibmc-cnrs.unistra.fr)

Competing interests: The authors declare that they have no competing interests.

Grant information: Work in our laboratories is funded by the Centre National de la Recherche Scientifique, the Agence Nationale de la Recherche (ANR-17-CE15-0014), the Investissements d'Avenir Program (ANR-10-LABX-0036 and ANR-11-EQPX-0022), the Institut Universitaire de France, the Chinese National Overseas Expertise Introduction Center for Discipline Innovation (Project 111 [D18010]), and the Foreign Expert Program (2020A1414010306).

The funders had no role in study design, data collection and analysis, decision to publish, or preparation of the manuscript.

Copyright: (C) 2021 Imler JL et al. This is an open access article distributed under the terms of the Creative Commons Attribution License, which permits unrestricted use, distribution, and reproduction in any medium, provided the original work is properly cited.

How to cite this article: Cai H and Imler JL. cGAS-STING: insight on the evolution of a primordial antiviral signaling cassette. Faculty Reviews 2021 10:(54) https://doi.org/10.12703/r/10-54

Published: 08 June 2021, Faculty Reviews 10:(54) https://doi.org/10.12703/r/10-54 


\section{Introduction}

Innate immunity is the first line of host defense that operates in all animals to counter infections. It relies on families of receptors known as pattern recognition receptors (PRRs) that sense molecular patterns shared by microorganisms but are absent from the host (e.g. bacterial lipopolysaccharides and fungal $\beta$-glucans) and trigger the expression of antimicrobial molecules and cytokines to counter the infection and alert the host of an infectious danger ${ }^{1}$. In mammals, innate immunity participates in activation of the $\mathrm{B}$ and $\mathrm{T}$ lymphocytes mediating adaptive immunity. Among infectious agents, viruses are a serious threat to all living organisms, be they animals, plants, fungi, protists, or even prokaryotes. They offer few targets for recognition, and triggering of antiviral immunity largely relies on sensing of viral RNA or DNA. As a result, all cells are equipped with powerful mechanisms to sense viral nucleic acids and restrict viruses. Some of these mechanisms are sequence specific and rely on RNA guides to specifically neutralize viral nucleic acids, e.g. CRISPR/Cas in prokaryotes or RNA interference (RNAi) in plants, fungi, and some invertebrates like worms and insects ${ }^{2,3}$. In vertebrates, nucleic acid-sensing PRRs, e.g. the Toll-like receptors TLR3 for double stranded (ds)-RNA, TLR7 for single stranded (ss)-RNA, or TLR9 for DNA in the endosomes and the RIG-I like receptors for uncapped and dsRNA in the cytosol, trigger a strong, dedicated transcriptional response to establish antiviral immunity (reviewed in 4,5). Among the genes induced by viruses in vertebrates, type I and type III interferon (IFN) cytokines play a major role in the antiviral response through induction or upregulation of hundreds of IFN-stimulated genes (ISGs) ${ }^{6}$. Importantly, nucleic acid-sensing PRRs have to distinguish between self and viral nucleic acids, and this discrimination is crucial because abnormal induction of IFN can lead to severe autoinflammatory diseases (reviewed in 5,7). Hence, investigation of these receptors and their regulation is of crucial importance.

In mammals, the presence of DNA in the cytosol is sensed by the enzyme cyclic guanosine monophosphate (GMP)-adenosine monophosphate (AMP) synthase (cGAS), which triggers the production of a cyclic dinucleotide (CDN) containing one phosphodiester bond between the $2^{\prime}$-hydroxyl of GMP and the 5'-phosphate of AMP and another between the 3'-hydroxyl of AMP and 5'-phosphate of GMP (2'3'-cGAMP) (Figure 1). Interestingly, cGAS shares closely related structural and enzymatic features with members of the IFN-regulated oligoadenylate synthase (OAS) family, which are encoded by ISGs $^{8}$. The three catalytically active members of the family in humans (OAS1, OAS2, and OAS3) produce a linear non-canonical RNA consisting of 3- to 30-nucleotide-long 2'-5'-linked oligoadenylates. This second messenger activates the latent ribonuclease RNase $\mathrm{L}$, another IFN-regulated gene, to promote the destruction of invading RNAs (Figure 2). The cGAS product 2'3'-cGAMP also acts as a second messenger, binding with nanomolar affinity to a receptor on the membranes of the endoplasmic reticulum: stimulator of IFN genes (STING). STING can also be activated by bacterial cyclic dinucleotides containing two $3^{\prime}-5^{\prime}$-phosphodiester linkages, such as $3^{\prime} 3^{\prime}$-cGAMP, c-di-GMP, and c-di-AMP, and can therefore activate innate immune responses independently from cGAS upon direct sensing of bacterial products (Figure 1). Upon activation, STING translocates to the membranes of the Golgi apparatus, where it engages the kinase TBK1 through its C-terminal tail (CTT), resulting in phosphorylation of the transcription factor IFN regulatory factor 3 (IRF3) and inducing transcription of the genes encoding type I and III IFN expression (reviewed in 8-10). Of note, STING is an evolutionarily conserved gene, and its presence in animals pre-dates the appearance of $\mathrm{IFNs}^{11}$. In particular, the sea anemone Nematostella vectensis, which shared a common ancestor with mammals over 600 million years ago, contains a cGAS enzyme producing 2'3'-cGAMP and a STING molecule to which it can bind, raising the question of the ancestral function of these molecules $^{12-14}$ (Figure 2).

Here, we first present recent developments with global relevance in the field of cGAS-STING signaling in mammals. We then discuss the IFN-independent functions of this signaling pathway in invertebrates. Finally, we review new findings revealing that cGAS antiviral signaling has its roots in prokaryotes, where it plays a major role in defense against bacteriophage infections.

\section{Novel insights on cGAS-STING signaling in mammals}

We emphasize here three recent developments in the field of cGAS-STING signaling, which relate to (i) the mechanisms regulating cGAS activity to prevent unwarranted activation of the pathway, (ii) the role of $2^{\prime} 3^{\prime}$-cGAMP as an immunotransmitter, and (iii) the function of STING beyond IFN regulation.

\section{Regulation of cGAS activity}

A central question in the field of cGAS-STING pertains to the mechanisms ensuring that signaling is not induced by self-nucleic acids (reverse transcribed RNA from active retroelements, damaged DNA escaping from the nucleus or stressed mitochondria). This question has important implications for understanding autoinflammatory conditions, e.g. STING-associated vasculopathy with onset in infancy (SAVI), but also neurodegenerative diseases such as Parkinson's disease, tumor growth, and aging (reviewed in 5,7). Two mechanisms controlling activation by self-DNA have recently emerged. First, DNA induces liquid phase condensation of cGAS, resulting in membrane-less droplets enriched in cGAS and DNA ${ }^{15,16}$. These subcellular condensates function as micro-reactors for highly efficient 2'3'-cGAMP production. Ligand-induced phase separation provides an astute mechanism to define a threshold concentration of DNA to activate the system and avoid reaction to low concentrations of cellular DNA in the cytosol. A second, more recently uncovered, mechanism relates to the regulation of the intracellular localization of cGAS, which does not primarily reside in the cytosol, as initially thought. Indeed, cGAS was reported to associate with the plasma membrane through interaction between its unstructured positively charged $\mathrm{N}$-terminus and negatively charged phosphoinositides ${ }^{17}$. However, an alternative explanation for the regulatory function of this $\mathrm{N}$-terminal 


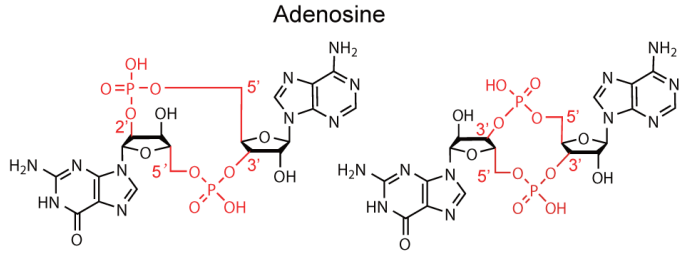

Guanosine

2'3'-cGAMP
3'3'-cGAMP

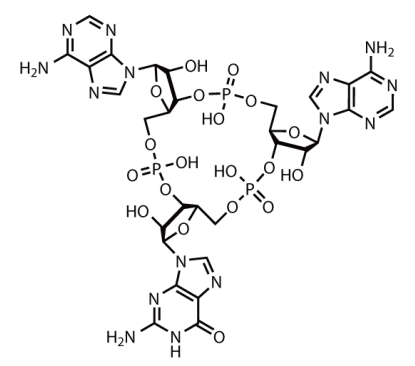

3'3'3'-cAMP-AMP-GMP

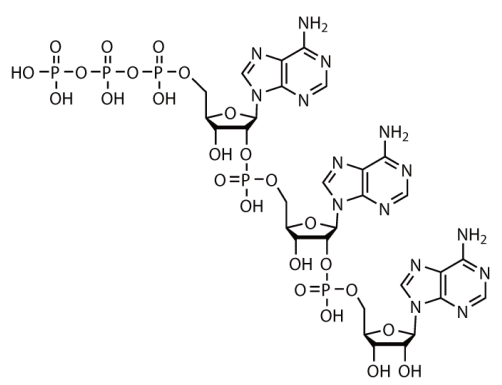

$\operatorname{pppAp}\left(2^{\prime}-5^{\prime}\right) A_{2}$

Figure 1. Oligonucleotide second messengers produced by CD-NTases across kingdoms. Cyclic guanosine monophosphate (GMP)adenosine monophosphate (AMP) synthase (cGAS)/DncV-like nucleotidyltransferases (CD-NTases) synthesize an array of cyclic or linear oligonucleotides connected by $2^{\prime}-5^{\prime}$ or $3^{\prime}-5^{\prime}$ bonds. $2^{\prime} 3^{\prime}-c G A M P$ and $2^{\prime}-5^{\prime}$ oligoadenylate - the trinucleotide pppAp $\left(2^{\prime}-5^{\prime}\right) A_{2}$ is shown-are produced by the mammalian enzymes cGAS and oligoadenylate synthase 1 (OAS1), respectively. 3'3'-cGAMP and 3'3'3'-cAMP-AMP-GMP are produced by the bacterial enzymes DncV (Vibrio cholerae) and EcCdnD02 (Enterobacter cloacae).

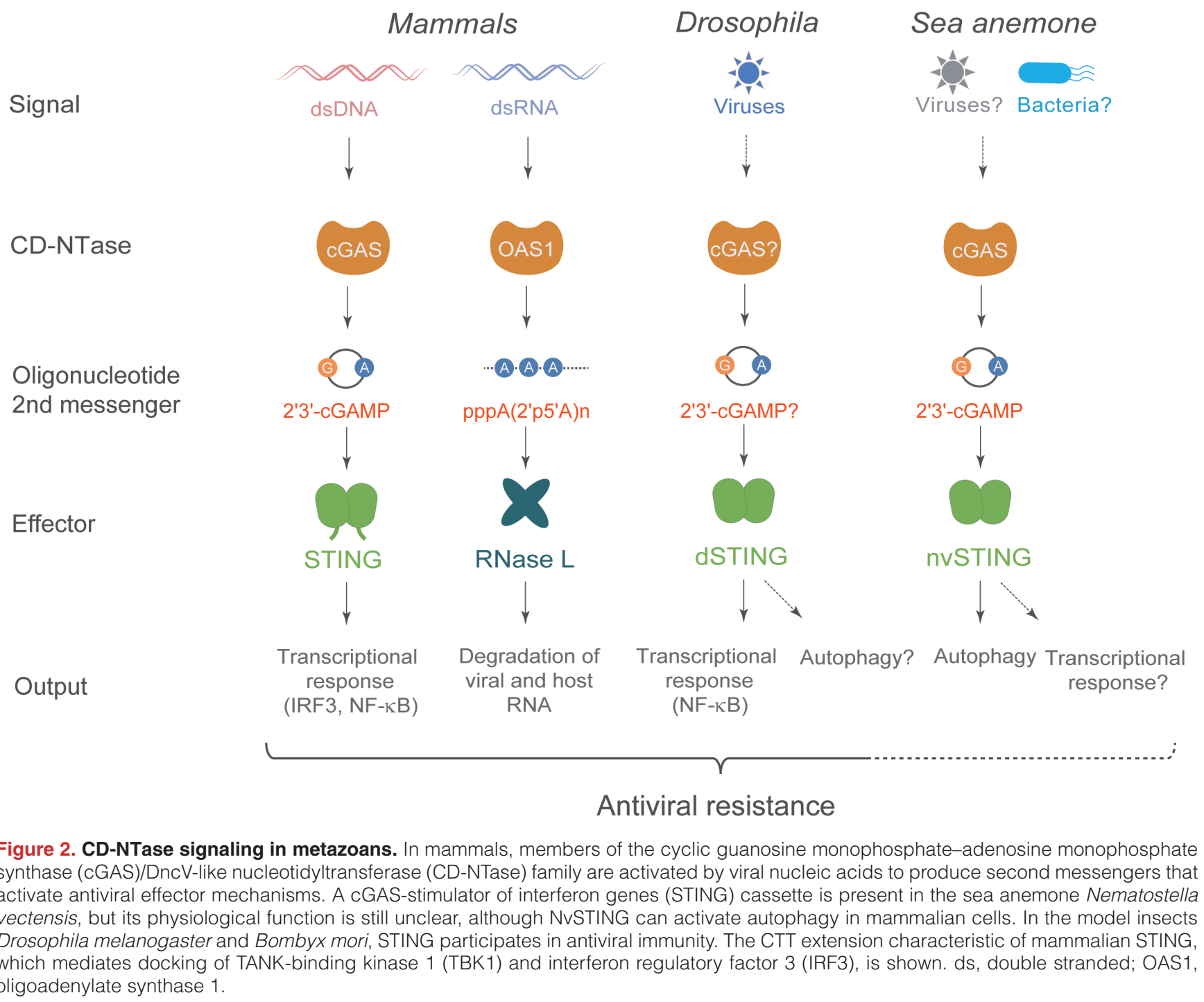


region, involving phosphorylation of several serine and threonine residues by mitotic kinases to prevent interaction with chromatin DNA upon nuclear envelope breakdown during mitosis, was recently provided ${ }^{18}$. More surprisingly and somewhat counterintuitively, a large number of cGAS molecules reside in the nucleus, where genomic DNA surrounds them ${ }^{19,20}$. Nuclear cGAS binds tightly to a negatively charged acidic patch formed by the histones $\mathrm{H} 2 \mathrm{~A}$ and $\mathrm{H} 2 \mathrm{~B}$ in addition to nucleosomal DNA. This inhibits oligomerization of cGAS, trapping it into an inactive state in the nucleus ${ }^{21-25}$. Barrier-to-autointegration factor 1 (BAF) also participates in the restriction of cGAS activity in the nucleus by displacing transiently bound cGAS molecules from genomic DNA ${ }^{26}$. While future studies will be required to understand the mechanisms controlling the distribution of cGAS in the nucleus versus the cytosol, in particular during infection, this recent discovery provides a tantalizing model for the control of cGAS activity in the absence of infection, with nucleosomes acting as a hallmark of self-DNA. Of note, these results also raise fascinating questions of possible as-yet-unknown nuclear-specific functions of cGAS (e.g. 27,28).

\section{$2^{\prime} 3^{\prime}$-cGAMP can function as an immunotransmitter}

It was realized early on that $2^{\prime} 3^{\prime}$-cGAMP did not function solely as a second messenger in a cell autonomous manner but was able to trigger antiviral immunity in adjacent cells by diffusion through gap junctions ${ }^{29}$ or upon packaging in virions $^{30,31}$. It is now apparent that this $\mathrm{CDN}$ also functions as an immunotransmitter released from infected cells into the extracellular space and diffusing to bystander cells, which it enters through either the folate-organic phosphate antiporter SLC19A1 or LRRC8 volume-regulated anion channels (VRACs) ${ }^{32-35}$. These transporters probably operate in a cell type-specific and context-dependent manner to amplify antiviral innate immunity and efficiently prevent virus spreading. The secreted enzyme ectonucleotide pyrophosphatase phosphodiesterase 1 (ENPP1) modulates this immune response by hydrolyzing extracellular $2^{\prime} 3^{\prime}$-cGAMP ${ }^{36}$. Importantly, transport of extracellular 2'3'-cGAMP into macrophages and other immune cells, and subsequent STING activation, enhances antitumor immunity ${ }^{37,38}$. Inhibitors of ENPP1 potentiate the antitumor response ${ }^{39,40}$.

\section{IFN-independent activities of mammalian STING}

Although STING was initially discovered for its role in the regulation of IFN gene expression, and the IFN response is the best-understood aspect of STING signaling in mammals, IFN-independent functions are emerging for the cGAS-STING pathway. Indeed, upon activation, STING can also activate (i) the transcription factor NF- $\mathrm{BB}$, leading to inflammation, (ii) autophagy, and (iii) the unfolded protein response (UPR) $)^{14,41-44}$. STING was also reported to inhibit translation ${ }^{45}$. Of note, the expression in mice of STING gain-of-function alleles mimicking the mutations observed in SAVI patients triggers IRF3- and IFN-independent immune cell dysregulation ${ }^{46,47}$. This highlights the importance of investigating the function of STING beyond regulation of IFN. As mentioned above, signaling by STING involves recruitment of the kinase TBK1 and the transcription factor IRF3 to the CTT domain of STING. Interestingly, this CTT domain is characteristic of vertebrate animals and seems to have emerged simultaneously with
IFNs $^{13}$. A comparative study of the signaling function of the CTT domain from 20 vertebrate STINGs revealed that 18 of them (the exceptions being the molecules from two Xenopus species [amphibians]) mediated the activation of IRF3 and NF- $\kappa \mathrm{B}$ when expressed in human cells ${ }^{48}$. Induction of IRF3-dependent transcription was always stronger than that of NF- $\kappa \mathrm{B}$, with the interesting difference of the molecules from salmon and zebrafish, for which induction of NF- $\mathrm{kB}$ was stronger than that of IRF3 by more than 100 -fold. In ray-finned fishes, the CTT domain gained a sequence motif mediating the recruitment of TRAF6, resulting in rewiring of signaling and explaining the bias towards NF- $\mathrm{KB}$ signaling. Overall, this study revealed that (i) the CTT domain is composed of discrete modules driving different signaling outputs according to the species and (ii) the activation of IRF3 does not represent the major transcriptional output of signaling in all vertebrate species ${ }^{48}$.

Characterization of STING signaling revealed a key role for the phosphorylation of the serine at position 365 in the CTT domain of mouse STING in the recruitment and subsequent activation of IRF3 by TBK1. As a result, knock-in mutant mice in which this critical serine residue has been replaced by an alanine (S365A mutants) fail to induce IFN upon stimulation of the pathway. However, autophagy and NF- $\kappa \mathrm{B}$ signaling can still be induced by STING in these mice, providing a powerful tool to unravel the relevance of the IFN-independent signaling arm downstream of STING in vivo. Strikingly, these mice were found to be resistant to infection by herpes simplex virus (HSV)-1, revealing that interferons are not absolutely required for the antiviral function of $\mathrm{STING}^{49,50}$. Yan and collaborators went on to study the transcriptome of bone marrow-derived macrophages (BMDMs) and $\mathrm{T}$ cells from wild-type and STING ${ }^{365 A}$ mutant mice stimulated with DMXAA, a potent STING agonist. This revealed striking differences between the two cell types, with a largely IFN-independent STING signaling in $\mathrm{T}$ cells compared to $\mathrm{BMDMs}^{50}$. These results reveal that STING plays a broader role than previously thought based on studies that initially investigated the innate arm of immunity and focused mainly on cells of the myeloid lineage. Identification of critical residues in STING for other signaling outputs, e.g. NF- $\kappa \mathrm{B}$, autophagy, and the UPR, will allow the establishment of mouse models to investigate the contribution of these pathways to STING signaling in vivo, as described above for S365A and activation of IRF3. For example, STING knock-in mutant mice with the mutation L373A, which prevents the recruitment of TBK1 and the activation of both IRF3 and $\mathrm{NF}-\kappa \mathrm{B}$, have impaired antiviral and antitumor activity, revealing the contribution of the evolutionarily conserved transcription factors $\mathrm{NF}-\kappa \mathrm{B}$ to STING function ${ }^{51}$. Interestingly, several recent studies have begun to shed light on the origins of cGAS-STING signaling and point to an ancestral function in connection with NF-kB signaling.

\section{Function and regulation of the cGAS-STING cassette in invertebrate animals}

Bioinformatics analyses have revealed the presence of STING orthologs in the genome of most animals, with some intriguing exceptions, e.g. nematodes and mosquitoes ${ }^{11,13}$. A STING ortholog is also present in the genome of choanoflagellates, 
a small group of single-cell or colonial protists representing the closest living unicellular relative of animals. Remarkably, STING from animals as diverse as the worm Capitella teleta (Annelida), the oyster Crassostrea gigas (Mollusca), and the sea anemone Nematostella vectensis (Cnidaria) were found to be able to bind both $3^{\prime} 3^{\prime}-\mathrm{CDNs}$ and 2'3'-cGAMP. Moreover, a cGAS-like gene from $N$. vectensis encodes an enzyme producing $2^{\prime} 3^{\prime}$-cGAMP ${ }^{12,14}$ (Figure 2). These observations raise questions about the function of the cGAS-STING cassette in early metazoans: is it involved in antibacterial or antiviral immunity? What kind of response does it trigger in organisms devoid of IFNs?

\section{STING and antiviral immunity in the model insect Drosophila}

Although the STING gene is absent from the genome of the nematode Caenorhabditis elegans, it is present in another well-characterized invertebrate model organism, the fruit fly Drosophila melanogaster ${ }^{11}$. Innate immunity in Drosophila involves (i) a cellular response with dedicated blood cells phagocytosing microorganisms or infected dying cells, encapsulating invading parasites, or producing melanin and toxic reactive oxygen species $^{52}$ and (ii) a humoral response characterized by the inducible expression of a cocktail of potent antimicrobial peptides (AMPs). Surface epithelia also play an important role in the control of infections in flies ${ }^{53}$. Of note, induction of AMPs is regulated by two evolutionarily conserved signaling pathways, Toll and IMD, which control the activity of transcription factors of the NF- $\kappa \mathrm{B}$ family, DIF and Relish, respectively. While the Toll pathway shares similarities with the IL-1R signaling pathway, the IMD pathway is evocative of the TNF receptor pathway ${ }^{54}$. In addition, RNAi plays a critical role in the control of viral infection. Viral double-stranded RNAs generated during replication are processed into 21-nucleotide-long small interfering (si) RNAs by the RNase III enzyme Dicer-2, and then loaded onto Argonaute-2, an RNase H-like enzyme using siRNAs as guides to target viral RNAs ${ }^{55}$. Viral infection in Drosophila is also associated with upregulation of a large number of genes, evocative of an induced response to viral infection ${ }^{56}$. The recent discovery of IFN-like immune responses in oysters indeed supports the existence of such a response in invertebrates ${ }^{57}$. The function of STING in innate immunity in Drosophila only recently came into the spotlight.

Noting the presence of a STING gene in flies (dSTING), Goodman and collaborators first reported impaired induction of the IMD pathway following infection of $d S T I N G$ mutant flies by the intracellular bacteria Listeria monocytogenes and impaired resistance to the infection. No phenotype was observed in flies mutant for CG7194, the closest homolog to cGAS in Drosophila, but AMPs could be induced by the bacterial CDN $3^{\prime} 3^{\prime}$ c-di-GMP. Overall, these data led the authors to propose that, in Drosophila, STING functions as a direct sensor of bacteria, through binding of CDNs, and activates an IMD- and Relish-dependent antibacterial response ${ }^{58}$. By contrast, two other studies connected STING to antiviral immunity, although through different mechanisms. Using the fly model to unravel the mechanisms of innate defense against Zika virus (ZIKV), which causes neurological complications, Cherry and colleagues observed that infection triggers the activation of the IMD pathway in the fly brain and that flies mutant for Relish or peptidoglycan recognition protein (PGRP)-LC and -LE, two PRRs activating the IMD pathway, were more susceptible to infection than controls. They further showed that STING expression was induced by ZIKV infection and that this induction depended on Relish, suggesting that STING functions as an NF- $\kappa \mathrm{B}-$ regulated antiviral effector. STING was indeed found to induce autophagy in the Drosophila brain, which was associated with protection against ZIKV ${ }^{59}$. Finally, our group followed up on the observation that a number of insect DNA viruses independently hijacked a gene encoding an immunomodulatory cytokine downregulating the activation of the IMD pathway ${ }^{60}$. This prompted a thorough investigation of the contribution of this pathway to antiviral immunity, which revealed that two of its components, the kinase IKK $\beta$ and Relish, but not the pathway as a whole, are required in a cell line and in vivo to resist infection by two picorna-like viruses. Genome-wide analysis revealed that one of the genes induced by these viruses with positive-sense (+)ssRNA genomes in an IKK $\beta$ - and Relishdependent manner was dSTING. Investigation of its function revealed that dSTING acts upstream of IKK $\beta$ and Relish in a pathway different from the IMD pathway and regulating the expression of a distinct set of genes ${ }^{61}$. More recently, we reported that injection of CDNs in flies results in the induction of STING-regulated genes (SRGs) and protection against viral infections. Importantly, this protection is completely dependent on dSTING and Relish but does not require ATG7 and AGO2, two key components of canonical autophagy and RNAi, respectively ${ }^{62}$. While the function of SRGs remains largely unknown, two of them, Vago and Nazo, have been shown to participate in antiviral resistance ${ }^{61-63}$. This study further revealed that, although $3^{\prime} 3^{\prime} \mathrm{CDNs}$ derived from bacteria can activate dSTING, the strongest agonist is $2^{\prime} 3^{\prime}$-cGAMP, suggesting that an enzyme producing this $\mathrm{CDN}$ is present in flies. Interestingly, a study in another insect, the silkworm Bombyx mori, connected STING to Relish activation in response to infection with nucleopolyhedrovirus (NPV), a DNA virus from the Baculoviridae family. These authors further detected the production of cGAMP in a silkworm cell line following viral infection ${ }^{64}$.

Overall, these studies reveal that insect STING regulates $\mathrm{NF}-\kappa \mathrm{B}$-dependent responses and is involved in antiviral immunity, although a participation in antibacterial immunity may also be possible ${ }^{58}$ (but see also ${ }^{61,62}$ ) (Figure 2). While STING may also regulate autophagy to control ZIKV in Drosophila, the biological significance of this finding is unclear since mosquitoes do not contain a STING gene and autophagy is proviral for ZIKV in mammalian cells ${ }^{65}$. The identification of genes encoding cGAMP nucleases in the genomes of Lepidopteran hosts and viruses further points to a key role of cGAS-STING signaling in antiviral immunity in insects.

\section{The poxin family of $2^{\prime} 3^{\prime}$-cGAMP nucleases radiated from} insect viruses

As expected from the pressure the cGAS-STING pathway exerts on them, several viruses have evolved suppressor mechanisms (reviewed in 66). Among them, poxins are $2^{\prime} 3^{\prime}$-cGAMP-specific nucleases that owe their name to the family 
of the virus in which they were first identified, vaccinia virus (VACV, a member of the Poxviridae) ${ }^{67}$. Sometimes fused to a C-terminal domain related to Schlafen proteins, poxins prevent the induction of the STING-TBK1-IRF3 signaling axis in mammalian cells, in effect allowing the viruses to escape a potent IFN response ${ }^{67,68}$. Intriguingly, the closest homologs to VACV poxin are found in the genomes of insect DNA viruses of the Alphabaculovirus genus but also in the genome of Lepidopteran insects, which host these viruses. Importantly, these insect poxins share with their homologs from mammalian viruses the specificity for $2^{\prime} 3^{\prime}$-cGAMP and fail to cleave 3'3'-cGAMP, providing further evidence that $\mathrm{CDNs}$ with a $2^{\prime}-5^{\prime}$ linkage play a significant role in antiviral immunity in insects ${ }^{67}$. Determination of the X-ray crystal structure of baculovirus and Lepidopteran host poxins revealed a relationship with self-cleaving viral proteases that operate to process the polyproteins translated from (+)ssRNA viruses. Based on these results, functional poxin enzymes could be identified in several insect-specific RNA viruses, some of which retained the self-cleaving protease activity ${ }^{69}$. The picture emerging from these data is that poxins originated from insect viral proteases, which acquired a secondary nuclease activity. These genes were subsequently endogenized in the genomes of the insect hosts for these viruses and eventually transferred to poxviruses, which have a notorious ability to acquire genes through horizontal transfer. The biochemical characterization of two viral poxins (from VACV and the baculovirus Autographa californica nuclear polyhedrosis virus, AcNPV) and one host-encoded poxin (from the cabbage looper Trichoplusia ni) pointed to interesting differences between the cellular and viral homologs. Indeed, both viral poxins display comparable high affinity for $2^{\prime} 3^{\prime}$-cGAMP compared to the $T$. ni poxin. By contrast, the host-encoded poxin tested exhibits a higher reaction rate constant than the two viral proteins ${ }^{69}$. Although these results will of course need to be extended to other members of the family, the differences observed suggest that viral poxins are tailored for immune evasion through efficient depletion of even low levels of $2 ' 3$ '-cGAMP, whereas host poxins may function as immunomodulators, regulating the level of second messenger produced and clearing excessive amounts to avoid deleterious overactivation of the pathway ${ }^{69}$. The fact that host-encoded poxins appear to be upregulated by infection in two transcriptomic studies support such a role, although, here again, additional functional studies in Lepidopteran insects are warranted. In this regard, one last intriguing observation made by Kranzusch and collaborators is that many poxin genes, both viral and cellular, express isoforms with and without signal peptides for secretion $^{69}$. Therefore, these enzymes could function in the cytosol, but also extracellularly, suggesting that the role of $2^{\prime} 3^{\prime}$-cGAMP as an immunotransmitter recently reported in mammals is evolutionarily ancient. Investigation of the function and regulation of these isoforms will clarify the role of 2 '3'-cGAMP in the infected cells but also in systemic responses to viral infection in insects.

\section{cGAS-STING signaling originated in bacteria}

As mentioned above, bacteria produce CDNs to control a diverse set of cellular responses, such as growth, osmoregulation, chemotaxis, and virulence ${ }^{70}$. Three distinct structural families of CDN synthases producing these CDNs have so far been identified: (i) the GGDEF c-di-GMP synthase family, (ii) the DAC/DisA c-di-AMP synthase family, and (iii) the cGAS/ DncV-like nucleotidyltransferase (CD-NTase) family. Whereas the first two families encompass prokaryotic proteins, the last one-as indicated by its name-contains both prokaryotic and eukaryotic proteins, including mammalian $\mathrm{cGAS}^{71}$. In bacteria, CD-NTases catalyze the production of a range of cyclic dinucleotides and trinucleotides (CTNs). These results reveal the ancient origin of CD-NTases and raise the question of their function in bacteria.

\section{CD-NTases and antiphage immunity in bacteria}

One characteristic of antiphage defense systems in bacteria is that they involve genes clustered together in operons. Noticing that CD-NTases in bacteria frequently cluster with defense genes, Sorek and collaborators introduced the 4-genes operon containing the CD-NTase coding gene $D n c V$ from the bacteria Vibrio cholerae into a strain of Escherichia coli lacking this system and showed that it conferred resistance to an array of phages belonging to several families ${ }^{72}$. This protection required $D n c V$ and was lost when two amino acids essential for the catalytic activity of the enzyme were mutated. A second gene from the operon, encoding a patatin-like phospholipase, was found to be essential for broad defense against phages. This enzyme degrades the bacterial membrane, causing cell death and interrupting phage replication ${ }^{73}$. Importantly, the phospholipase can be activated in vitro by bacteria lysates collected after phage infection, in which $3^{\prime} 3^{\prime}$-cGAMP is detected by mass spectrometry. These results indicated that a cyclic oligonucleotide-based antiphage signaling system (CBASS) operates in bacteria to control phage infections, suggesting that the antiviral functions of cGAS and OAS in vertebrates were inherited from prokaryotes ${ }^{72}$. Of note, CBASS is not the only defense system producing nucleotide-based second messenger signals in bacteria. Indeed, the type III CRISPR/Cas system (a total of 6 different types of CRISPR/Cas have been identified in bacteria, each relying on a different set of Cas proteins) involves the large multidomain protein Cas10, which degrades foreign DNA but also generates 2- to 6-nucleotide-long cyclic oligoadenylates (cOA). cOA then bind to the CRISPR-associated Rossmann fold (CARF) domains of the homodimeric enzyme Csm6, triggering its RNase activity, thus interrupting phage replication $^{74,75}$ (Figure 3). This provides an intriguing conceptual similarity with the activation of RNase L by OAS-produced linear oligoadenylates in mammalian antiviral immunity.

\section{Some bacterial CD-NTases produce $2^{\prime}-5^{\prime}$ linked cyclic oligonucleotides to restrict phage infection}

Noting that the CBASS operons encoding bacterial CD-NTases often do not contain patatin-like phospholipases, Kranzusch and collaborators set out to identify other bacterial effectors regulated by CDNs or CTNs. This led to the identification of more than 2,000 effectors, including nucleases, proteases, $\beta$-nicotinamide adenine dinucleotide $\left(\mathrm{NAD}^{+}\right)$hydrolases, and putative pore-forming proteins ${ }^{76}$. All of these proteins, present in about one-third of sequenced operons containing a CD-NTase, share a SMODS-associated and fused to various effector domains (SAVED) domain, which accommodates the 
V. cholerae

Signal

Cyclic
oligonucleotide
synthase

Output
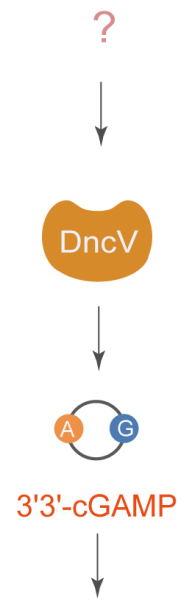

Effector

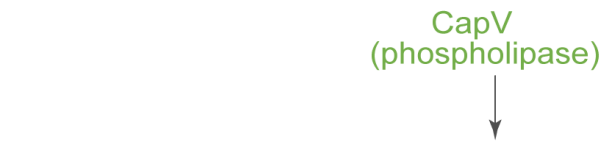

Degradation of cell membrane
E. cloacae
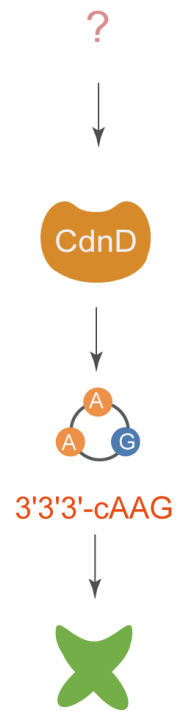

Cap4

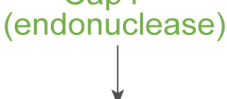

DNA cleavage

\section{Flavobacteriaceae sp. S. thermophilus}
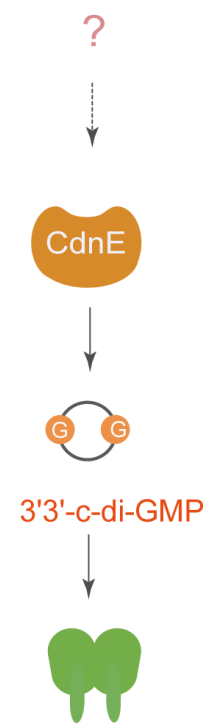

FsSTING

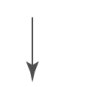

Degradation of NAD+
Csm6

(RNase)

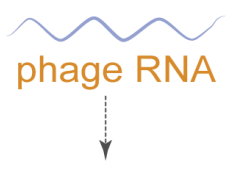

Cas10<smiles></smiles>

cyclic oligo-adenylates (cOA)

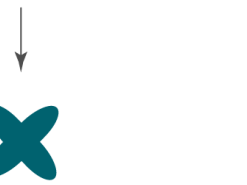

Degradation of viral and host RNA

\section{Anti-phage resistance}

Figure 3. Cyclic oligonucleotide-based antiphage signaling system (CBASS) in bacteria. In bacteria, members of the cyclic guanosine monophosphate-adenosine monophosphate synthase (cGAS)/DncV-like nucleotidyltransferase (CD-NTase) family are activated by an unknown mechanism in response to phage infection and produce second messengers that activate antiviral effector mechanisms. Cas10, an enzyme of the type III CRISPR/Cas system, is structurally distinct from CD-NTases but also synthesizes cyclic oligonucleotide second messengers that activate antiphage effectors. The CARF domain binding to cyclic oligo-adenylate in Csm6 is structurally related to the SAVED domains found in effectors of CBASS, e.g. Cap4. Note that bacterial FsSTING contains a TIR domain mediating the degradation of NAD+ upon activation. CARF, CRISPR-associated Rossmann fold; E. cloacae, Enterobacter cloacae; NAD+, $\beta$-nicotinamide adenine dinucleotide; SAVED, SMODS-associated and fused to various effector domains; S. thermophilus, Streptococcus thermophilus; STING, stimulator of interferon genes; TIR, Toll/interleukin-1 receptor; $V$. cholerae, Vibrio cholerae.

nucleotide second messenger. Unexpectedly, solving the structure of the SAVED domain unveiled two fused CARF domains, revealing convergence between CBASS and type III CRISPR/ Cas systems for the sensing of cyclic oligonucleotide second messengers. The potential for cross-talk between the two antiphage defense systems is reinforced by the observation that some type III CRISPR/Cas operons contain genes encoding SAVED domains $^{76,77}$. Of note, as mentioned above for Csm6, activation of type III CRISPR involves homodimeric CARF domaincontaining proteins, which change conformation upon binding to a ligand with twofold symmetry. Fusion of two CARF domains into a SAVED domain resulted in a domain able to accommodate a wide variety of cyclic oligonucleotide second messengers, including asymmetric ones. Indeed, the CD-NTase from Acinetobacter baumannii synthesized the CTN 2'3'3'-cAAA, demonstrating that $2^{\prime}-5^{\prime}$ phosphodiester linkages, although rare, are also present in bacteria, where they participate in antiphage defense $^{76}$. In summary, a large array of distinct oligonucleotides with different nucleobase composition, ring size, and $2^{\prime}-5^{\prime}$ or $3^{\prime}-5^{\prime}$ linkage, synthesized by a diversity of CD-NTase enzymes, activate a panel of different antiphage effector proteins in bacteria (Figure 3). This diversity probably offers an efficient safeguard against phage replication.

\section{Bacterial STING proteins function as CDN-regulated} antiphage effectors

Interestingly, bioinformatic analysis of phage defense operons revealed the presence of genes encoding proteins with 
predicted homology to STING ${ }^{72,78,79}$. Structural analysis revealed that these proteins indeed share the overall architecture of metazoan STING in spite of a $20 \%$ smaller size and more compact organization. Notably, bacterial STING binds to c-di-GMP and binds poorly or not at all to CDNs containing a $2^{\prime}-5^{\prime}$ linkage, including $2^{\prime} 3^{\prime}-$ cGAMP $^{78}$. Only a few bacterial STING proteins contain predicted transmembrane helices but most of them also contain a Toll/interleukin-1 (IL-1) receptor (TIR) domain. TIR domains are present in plant and animal proteins involved in host defense. While the TIR domain of Toll and IL-1 receptor families function as homotypic proteinprotein interaction domains to recruit signaling adaptors, some TIR domains in bacteria, plants, and animals have catalytic activity and degrade $\mathrm{NAD}^{+}$, which is essential for cellular metabolism ${ }^{80}$ Indeed, activation of a bacterial TIR-STING protein with c-di-GMP resulted in rapid and efficient hydrolysis of $\mathrm{NAD}^{+}$. Interestingly, this activation was accompanied by assembly of the TIR-STING proteins into filaments, as previously reported for human STING, which oligomerizes upon binding 2'3'-cGAMP, thus leading to TBK1 activation ${ }^{78,81}$.

In summary, both CD-NTase enzymes producing CDN signals and STING-like molecules acting as a receptor for this signal were already present and active in defense against viruses in prokaryotic cells (Figure 3). 2'-5' phosphodiester linkage in the CDNs is also present in some bacteria, although not in connection to STING activation. Overall, these results suggest that the eukaryotic ancestors of animals inherited each component of the cGAS-STING signaling pathway from their prokaryotic precursors, a hypothesis supported by the identification of STING-TIR fusion proteins in some metazoans, e.g. oysters ${ }^{78}$.

\section{Concluding remarks}

The field of cGAS-STING signaling has seen a number of significant new developments in recent years. Not least among them, we now have a clear idea of the origin of the molecules composing the cGAS-STING signaling cassette, which arose in prokaryotes, where they participate in defense against bacteriophages. STING signaling is also emerging as an important antiviral mechanism in insects, suggesting a striking structural and functional conservation of this cassette during evolution to restrict viruses, a universal threat for cellular life. Argonaute proteins represent another example of ancient and conserved factors participating in antiviral restriction in all domains of life $\mathrm{e}^{82}$. One intriguing difference between cGAS-STING signaling in mammals and that in bacteria is the use of a mix of $2^{\prime}-5^{\prime}$ and $3^{\prime}-5^{\prime}$ linkages in the products of cGAS and OAS, whereas in the vast majority of cases bacteria favor a $3^{\prime}-5^{\prime}$ linkage. It is now clear that these differences can have important consequences for both activation of downstream effectors and degradation by nucleases ${ }^{36,69}$. Mammalian and insect STING detect both 2'3'- and 3'3'-CDNs but appear to favor 2'3'-cGAMP as a ligand ${ }^{9,62}$, and the cGAS enzyme from the sea anemone produces $2^{\prime} 3^{\prime}-\mathrm{cGAMP}^{14}$, raising the possibility that the $2^{\prime}-5^{\prime}$ linkage was co-opted in metazoans to increase the signal-to-noise ratio in the context of viral infections in multicellular organisms tightly associated with a microbial flora. The identification and characterization of additional cGAS enzymes in invertebrates will undoubtedly clarify this issue.

As for all active fields of research, the recent insights on cGAS-STING signaling raise new fascinating questions. Regarding the evolution of the pathway, one of them is the regulation of the activation of CD-NTases in bacteria, which seem to be constitutively active in vitro ${ }^{71,72,76}$. Do CD-NTases respond to changes in the cell (e.g. altered metabolism and modification of HORMA-domain proteins ${ }^{83}$ ) or can they be activated upon sensing viral components like PRRs in animals and as shown for Cas10 (a GGDEF-type synthase), which is activated by phage RNA in Streptococcus thermophilus ${ }^{74,75}$ ? Similarly, how is the STING pathway activated in invertebrate animals? It has been noted that the zinc ribbon present in mammalian cGAS and important for DNA sensing is absent from cGAS-like molecules in invertebrates ${ }^{13}$. This suggests that these candidate PRRs may respond to another type of nucleic acid, a hypothesis consistent with the fact that STING is activated by RNA viruses in flies ${ }^{59,61}$. Another question raised by the numerous different effector molecules activated by CDNs and CTNs in bacteria is whether CDNs can activate receptors other than STING in animals. The only such alternative receptor reported today, the mouse oxidoreductase RECON, can sense bacterial CDNs and CTNs and controls NF- $\kappa$ B activity ${ }^{71,84,85}$.

To conclude, it is remarkable that, in parallel to the significant progress made during the past 2 years on the understanding of the evolutionary history of cGAS/STING signaling, exciting new developments occurred in mammals, testifying to the liveliness of a field where much remains to be learned. One consequence of the emerging conservation of the pathway in invertebrates is that model organisms like Drosophila may provide some insights on still-mysterious facets of cGAS/STING biology. Elucidation of the mechanism through which STING activates IKK $\beta$ and Relish in Drosophila can, for example, be expected to shed light on the still-elusive activation of $\mathrm{NF}-\kappa \mathrm{B}$ by STING in mammals. The fact that Lepidopteran insects appear to secrete poxins ${ }^{62}$ and that injection of $2^{\prime} 3^{\prime}$-cGAMP in the body cavity of flies results in strong antiviral protection ${ }^{62}$ argue that the function of this $\mathrm{CDN}$ as an immunotransmitter is evolutionarily ancient and could be studied using the genetic resources of the Drosophila model. Finally, it will be interesting to see where the invertebrate cGAS enzymes reside. Should they also be located in the nucleus, model organisms like Drosophila will be ideally suited to decipher their role and regulation in this critical cellular compartment.

\section{Acknowledgements}

We thank Carine Meignin (University of Strasbourg) and Nelson Martins (Instituto Gulbenkian de Ciência, Lisbon) for discussions and comments on the manuscript. 
1. Hoffmann JA, Kafatos FC, Janeway CA, et al.: Phylogenetic perspectives in innate immunity. Science. 1999; 284(5418): 1313-8. PubMed Abstract | Publisher Full Text

2. Horvath $P$, Barrangou R: CRISPR/Cas, the immune system of bacteria and archaea. Science. 2010; 327(5962): 167-70. PubMed Abstract | Publisher Full Text

3. Guo Z, Li Y, Ding SW: Small RNA-based antimicrobial immunity. Nat Rev Immunol. 2019; 19(1): 31-44.

PubMed Abstract | Publisher Full Text

4. Kawai T, Akira S: Toll-like receptors and their crosstalk with other innate receptors in infection and immunity. Immunity. 2011; 34(5): 637-50. PubMed Abstract | Publisher Full Text

5. Roers A, Hiller B, Hornung V: Recognition of Endogenous Nucleic Acids by the Innate Immune System. Immunity. 2016; 44(4): 739-54.

PubMed Abstract | Publisher Full Text

6. Schneider WM, Chevillotte MD, Rice CM: Interferon-stimulated genes: A complex web of host defenses. Annu Rev Immunol. 2014; 32: 513-45. PubMed Abstract | Publisher Full Text | Free Full Text

7. Uggenti C, Lepelley A, Crow YJ: Self-Awareness: Nucleic Acid-Driven Inflammation and the Type I Interferonopathies. Annu Rev Immunol. 2019; 37 $247-67$.

PubMed Abstract | Publisher Full Text

8. Hornung V, Hartmann R, Ablasser A, et al:: OAS proteins and cGAS: Unifying concepts in sensing and responding to cytosolic nucleic acids. Nat Rev Immunol. 2014; 14(8): 521-8.

PubMed Abstract | Publisher Full Text | Free Full Text

9. Ablasser A, Chen ZJ: cGAS in action: Expanding roles in immunity and inflammation. Science. 2019; 363(6431): eaat8657. PubMed Abstract | Publisher Full Text

10. Zhang X, Bai XC, Chen ZJ: Structures and Mechanisms in the cGAS-STING Innate Immunity Pathway. Immunity. 2020; 53(1): 43-53. PubMed Abstract | Publisher Full Text

11. Wu X, Wu FH, Wang X, et al.: Molecular evolutionary and structural analysis of the cytosolic DNA sensor cGAS and STING. Nucleic Acids Res. 2014; 42(13): 8243-57.

PubMed Abstract | Publisher Full Text | Free Full Text

12. Kranzusch PJ, Wilson SC, Lee ASY, et al:: Ancient Origin of cGAS-STING Reveals Mechanism of Universal 2',3' cGAMP Signaling. Mol Cell. 2015; 59(6): 891-903.

PubMed Abstract | Publisher Full Text | Free Full Text |

Faculty Opinions Recommendation

13. Margolis SR, Wilson SC, Vance RE: Evolutionary Origins of cGAS-STING Signaling. Trends Immunol. 2017; 38(10): 733-43. PubMed Abstract | Publisher Full Text

14. Gui X, Yang H, Li T, et al.: Autophagy induction via STING trafficking is a primordial function of the cGAS pathway. Nature. 2019 ; $567(7747)$ : 262-6. PubMed Abstract | Publisher Full Text | Faculty Opinions Recommendation

15. Du M, Chen ZJ: DNA-induced liquid phase condensation of cGAS activates innate immune signaling. Science. 2018; 361(6403): 704-9.

PubMed Abstract | Publisher Full Text | Faculty Opinions Recommendation

16. Xie W, Lama L, Adura C, et al.: Human cGAS catalytic domain has an additional DNA-binding interface that enhances enzymatic activity and liquid-phase condensation. Proc Natl Acad Sci U S A. 2019; 116(24): 11946-55. PubMed Abstract | Publisher Full Text | Free Full Text

17. Barnett KC, Coronas-Serna JM, Zhou W, et al:: Phosphoinositide Interactions Position cGAS at the Plasma Membrane to Ensure Efficient Distinction between Self- and Viral DNA. Cell. 2019; 176(6): 1432-1446.e11. PubMed Abstract | Publisher Full Text | Free Full Text

18. Li T, Huang T, Du M, et al.: Phosphorylation and chromatin tethering prevent cGAS activation during mitosis. Science. 2021; 371(6535): eabc5386. PubMed Abstract | Publisher Full Text | Faculty Opinions Recommendation

19. Gentili M, Lahaye X, Nadalin F, et al.: The N-Terminal Domain of cGAS Determines Preferential Association with Centromeric DNA and Innate Immune Activation in the Nucleus. Cell Rep. 2019; 26(9): 2377-2393.e13. PubMed Abstract | Publisher Full Text | Free Full Text | Faculty Opinions Recommendation

20. Volkman HE, Cambier S, Gray EE, et al:: Tight nuclear tethering of cGAS is essential for preventing autoreactivity. Elife. 2019; 8: e47491. PubMed Abstract | Publisher Full Text | Free Full Text | Faculty Opinions Recommendation

21. Pathare GR, Decout A, Glück S, et al:: Structural mechanism of cGAS inhibition by the nucleosome. Nature. 2020; 587(7835): 668-72. PubMed Abstract | Publisher Full Text | Faculty Opinions Recommendation

22. Zhao B, Xu P, Rowlett CM, et al.: The molecular basis of tight nuclear tethering and inactivation of cGAS. Nature. 2020; 587(7835): 673-7. PubMed Abstract | Publisher Full Text | Free Full Text

23. Kujirai T, Zierhut C, Takizawa Y, et al:: Structural basis for the inhibition of cGAS by nucleosomes. Science. 2020; 370(6515): 455-8. PubMed Abstract | Publisher Full Text | Free Full Text | Faculty Opinions Recommendation

24. Boyer JA, Spangler CJ, Strauss JD: Structural basis of nucleosomedependent cGAS inhibition. Science. 2020; 370(6515): 450-4. PubMed Abstract | Publisher Full Text | Faculty Opinions Recommendation

25. Michalski S, de Oliveira Mann CC, Stafford CA, et al:: Structural basis or sequestration and autoinhibition of cGAS by chromatin. Nature. 2020; 587(7835): 678-82

PubMed Abstract | Publisher Full Text | Faculty Opinions Recommendation

26. Guey B, Wischnewski M, Decout A, et al: BAF restricts cGAS on nuclear DNA to prevent innate immune activation. Science. 2020; 369(6505): 823-8. PubMed Abstract | Publisher Full Text | Faculty Opinions Recommendation

27. Jiang $\mathrm{H}$, Xue X, Panda S, et al:: Chromatin-bound cGAS is an inhibitor of DNA repair and hence accelerates genome destabilization and cell death. EMBO J. 2019; 38(21): e102718.

PubMed Abstract | Publisher Full Text | Free Full Text | Faculty Opinions Recommendation

28. Zierhut C, Yamaguchi N, Paredes M, et al:: The Cytoplasmic DNA Sensor cGAS Promotes Mitotic Cell Death. Cell. 2019; 178(2): 302-315.e23. PubMed Abstract | Publisher Full Text | Free Full Text | Faculty Opinions Recommendation

29. Ablasser A, Schmid-Burgk JL, Hemmerling I, et al.: Cell intrinsic immunity spreads to bystander cells via the intercellular transfer of cGAMP. Nature. 2013; 503(7477): 530-4.

PubMed Abstract | Publisher Full Text | Free Full Text |

Faculty Opinions Recommendation

30. Gentili M, Kowal J, Tkach M, et al:: Transmission of innate immune signaling by packaging of cGAMP in viral particles. Science. 2015; 349(6253): 1232-6. PubMed Abstract | Publisher Full Text

31. Bridgeman A, Maelfait J, Davenne T, et al:: Viruses transfer the antiviral second messenger cGAMP between cells. Science. 2015; 349(6253): 1228-32. PubMed Abstract | Publisher Full Text | Free Full Text

32. Lahey LJ, Mardjuki RE, Wen X, et al.: LRRC8A:C/E Heteromeric Channels Are Ubiquitous Transporters of cGAMP. Mol Cell. 2020; 80(4): 578-591.e5. PubMed Abstract | Publisher Full Text

33. Luteijn RD, Zaver SA, Gowen BG, et al: SLC19A1 transports immunoreactive cyclic dinucleotides. Nature. 2019; 573(7774): 434-8. PubMed Abstract | Publisher Full Text | Free Full Text

34. Ritchie C, Cordova AF, Hess GT, et al:: SLC19A1 Is an Importer of the Immunotransmitter cGAMP. Mol Cell. 2019; 75(2): 372-381.e5. PubMed Abstract | Publisher Full Text | Free Full Text | Faculty Opinions Recommendation

35. Zhou C, Chen X, Planells-Cases R, et al:: Transfer of cGAMP into Bystander Cells via LRRC8 Volume-Regulated Anion Channels Augments STINGMediated Interferon Responses and Anti-viral Immunity. Immunity. 2020; 52(5): 767-781.e6.

PubMed Abstract | Publisher Full Text | Faculty Opinions Recommendation

36. Li L, Yin Q, Kuss P, et al:: Hydrolysis of 2'3'-cGAMP by ENPP1 and design of nonhydrolyzable analogs. Nat Chem Biol. 2014; 10(12): 1043-8. PubMed Abstract | Publisher Full Text | Free Full Text

37. Zhou Y, Fei M, Zhang G, et al.: Blockade of the Phagocytic Receptor MerTK on Tumor-Associated Macrophages Enhances P2X7R-Dependent STING Activation by Tumor-Derived cGAMP. Immunity, 2020; 52(2): 357-373.e9. PubMed Abstract | Publisher Full Text | Faculty Opinions Recommendation

38. Marcus A, Mao AJ, Lensink-Vasan M, et al.: Tumor-Derived cGAMP Triggers a STING-Mediated Interferon Response in Non-tumor Cells to Activate the NK Cell Response. Immunity. 2018; 49(4): 754-763.e4. PubMed Abstract | Publisher Full Text | Free Full Text

39. Carozza JA, Brown JA, Böhnert V, et al:: Structure-Aided Development of Small-Molecule Inhibitors of ENPP1, the Extracellular Phosphodiesterase of the Immunotransmitter cGAMP. Cell Chem Biol. 2020; 27(11): 1347-1358.e5. PubMed Abstract | Publisher Full Text | Free Full Text Faculty Opinions Recommendation

40. Carozza JA, Böhnert V, Nguyen KC, et al: Extracellular cGAMP is a cancer cell-produced immunotransmitter involved in radiation-induced anti-cancer immunity. Nat Cancer. 2020; 1(2): 184-96. PubMed Abstract | Publisher Full Text | Free Full Text Faculty Opinions Recommendation 
41. Cerboni S, Jeremiah N, Gentili M, et al:: Intrinsic antiproliferative activity of the innate sensor STING in T lymphocytes. J Exp Med. 2017; 214(6): 1769-85. PubMed Abstract | Publisher Full Text | Free Full Text | Faculty Opinions Recommendation

42. Wu J, Chen YJ, Dobbs N, et al:: STING-mediated disruption of calcium homeostasis chronically activates ER stress and primes T cell death. J Exp Med. 2019; 216(4): 867-83.

PubMed Abstract | Publisher Full Text | Free Full Text |

Faculty Opinions Recommendation

43. Moretti J, Roy S, Bozec D, et al.: STING Senses Microbial Viability to Orchestrate Stress-Mediated Autophagy of the Endoplasmic Reticulum. Cell. 2017; 171(4): 809-823.e13.

PubMed Abstract | Publisher Full Text | Free Full Text |

Faculty Opinions Recommendation

44. Watson RO, Bell SL, MacDuff DA, et al: The Cytosolic Sensor cGAS Detects Mycobacterium tuberculosis DNA to Induce Type I Interferons and Activate Autophagy. Cell Host Microbe. 2015; 17(6): 811-9.

PubMed Abstract | Publisher Full Text | Free Full Text

45. Franz KM, Neidermyer WJ, Tan YJ, et al:: STING-dependent translation inhibition restricts RNA virus replication. Proc Natl Acad Sci U S A. 2018; 115(9): E2058E2067.

PubMed Abstract | Publisher Full Text | Free Full Text

46. Couis D, Kirstetter P, Arbogast F, et al:: Severe combined immunodeficiency in stimulator of interferon genes (STING) V154M/wild-type mice. J Allergy Clin Immunol. 2019; 143(2): 712-725.e5.

PubMed Abstract | Publisher Full Text | Faculty Opinions Recommendation

47. Warner JD, Irizarry-Caro RA, Bennion BG, et al.: STING-associated vasculopathy develops independently of IRF3 in mice. J Exp Med. 2017; 214(11): 3279-92. PubMed Abstract | Publisher Full Text | Free Full Text

48. de Oliveira Mann CC, Orzalli MH, King DS, et al.: Modular Architecture of the STING C-Terminal Tail Allows Interferon and NF-кB Signaling Adaptation. Cell Rep. 2019; 27(4): 1165-1175.e5.

PubMed Abstract | Publisher Full Text | Free Full Text |

Faculty Opinions Recommendation

49. Yamashiro LH, Wilson SC, Morrison HM, et al:: Interferon-independent STING signaling promotes resistance to HSV-1 in vivo. Nat Commun. 2020; 11(1): 3382.

PubMed Abstract | Publisher Full Text | Free Full Text |

Faculty Opinions Recommendation

50. Wu J, Dobbs N, Yang K, et al.: Interferon-Independent Activities of Mammalian STING Mediate Antiviral Response and Tumor Immune Evasion. Immunity. 2020; 53(1): 115-126.e5.

PubMed Abstract | Publisher Full Text | Free Full Text |

Faculty Opinions Recommendation

51. CYum S, Li M, Fang Y, et al:: TBK1 recruitment to STING activates both IRF3 and NF-кB that mediate immune defense against tumors and viral infections. Proc Natl Acad Sci U S A. 2021; 118(14): e2100225118. PubMed Abstract | Publisher Full Text | Free Full Text | Faculty Opinions Recommendation

52. Letourneau M, Lapraz F, Sharma A, et al: Drosophila hematopoiesis under normal conditions and in response to immune stress. FEBS Lett. 2016; 590(22): 4034-51.

PubMed Abstract | Publisher Full Text

53. Buchon N, Silverman N, Cherry S: Immunity in Drosophila melanogaster--from microbial recognition to whole-organism physiology. Nat Rev Immunol. 2014; 14(12): 796-810

PubMled Abstract | Publisher Full Text | Free Full Text

54. Hoffmann JA: The immune response of Drosophila. Nature. 2003; 426(6962): 33-8.

PubMed Abstract | Publisher Full Text

55. Bronkhorst AW, van Rij RP: The long and short of antiviral defense: Small RNAbased immunity in insects. Curr Opin Virol. 2014; 7: 19-28.

PubMed Abstract | Publisher Full Text

56. Schneider J, Imler JL: Sensing and signalling viral infection in drosophila. Dev Comp Immunol. 2021; 117: 103985.

PubMed Abstract | Publisher Full Text

57. Lafont M, Vergnes A, Vidal-Dupiol J, et al.: A Sustained Immune Response Supports Long-Term Antiviral Immune Priming in the Pacific Oyster, Crassostrea gigas. $m B$ Bio. 2020; 11(2): e02777-19.

PubMed Abstract | Publisher Full Text | Free Full Text | Faculty Opinions Recommendation

58. Martin M, Hiroyasu A, Guzman RM, et al.: Analysis of Drosophila STING Reveals an Evolutionarily Conserved Antimicrobial Function. Cell Rep. 2018; 23(12): 3537-3550.e6.

PubMed Abstract | Publisher Full Text | Free Full Text

59. Liu Y, Gordesky-Gold B, Leney-Greene M, et al:: Inflammation-Induced, STINGDependent Autophagy Restricts Zika Virus Infection in the Drosophila Brain. Cell Host Microbe. 2018; 24(1): 57-68.e3.

PubMed Abstract | Publisher Full Text | Free Full Text
60. Lamiable O, Kellenberger C, Kemp C, et al.: Cytokine Diedel and a vira homologue suppress the IMD pathway in Drosophila. Proc Natl Acad Sci U S A. 2016: 113(3): 698-703.

PubMed Abstract | Publisher Full Text | Free Full Text

61. Goto A, Okado K, Martins N, et al.: The Kinase IKK $\beta$ Regulates a STING- and NF-кB-Dependent Antiviral Response Pathway in Drosophila. Immunity. 2018; 49(2): 225-234.e4.

PubMed Abstract | Publisher Full Text | Free Full Text

62. Cai H, Holleufer A, Simonsen B, et al:: 2'3'-cGAMP triggers a STING- and NF-кBdependent broad antiviral response in Drosophila. Sci Signal. 2020; 13(660): eabc4537.

PubMed Abstract | Publisher Full Text

63. Deddouche S, Matt N, Budd A, et al.: The DExD/H-box helicase Dicer-2 mediates the induction of antiviral activity in drosophila. Nat Immunol. 2008; 9(12): 1425-32.

PubMed Abstract | Publisher Full Text | Faculty Opinions Recommendation

64. Hua X, Li B Song L, et al: Stimulator of interferon genes (STING) provides insect antiviral immunity by promoting Dredd caspase-mediated NF-kB activation. J Biol Chem. 2018; 293(30): 11878-90.

PubMed Abstract | Publisher Full Text | Free Full Text

65. Abernathy E, Mateo R, Majzoub K, et al:: Differential and convergent utilization of autophagy components by positive-strand RNA viruses. PLOS Biol. 2019 ; 17(1): e2006926.

PubMed Abstract | Publisher Full Text | Free Full Text

66. Eaglesham JB, Kranzusch PJ: Conserved strategies for pathogen evasion of cGAS-STING immunity. Curr Opin Immunol. 2020; 66: 27-34. PubMed Abstract | Publisher Full Text | Free Full Text

67. Eaglesham JB, Pan Y, Kupper TS, et al:: Viral and metazoan poxins are cGAMP-specific nucleases that restrict cGAS-STING signalling. Nature. 2019; 566(7743): 259-63.

PubMed Abstract | Publisher Full Text | Free Full Text |

Faculty Opinions Recommendation

68. Hernáez B, Alonso G, Georgana I, et al:: Viral cGAMP nuclease reveals the essential role of DNA sensing in protection against acute lethal virus infection. Sci Adv. 2020; 6(38): eabb4565.

PubMed Abstract | Publisher Full Text | Free Full Text | Faculty Opinions Recommendation

69. Eaglesham JB, McCarty KL, Kranzusch PJ: Structures of diverse poxin cGAMP nucleases reveal a widespread role for cGAS-STING evasion in hostpathogen conflict. Elife. 2020; 9: e59753.

PubMed Abstract | Publisher Full Text | Free Full Text |

Faculty Opinions Recommendation

70. Kranzusch PJ: cGAS and CD-NTase enzymes: Structure, mechanism, and evolution. Curr Opin Struct Biol. 2019; 59: 178-87. PubMed Abstract | Publisher Full Text | Free Full Text

71. Whiteley AT, Eaglesham JB, de Oliveira Mann CC, et al:: Bacterial cGAS-like enzymes synthesize diverse nucleotide signals. Nature. 2019; 567(7747): 194-9. PubMed Abstract | Publisher Full Text | Free Full Text | Faculty Opinions Recommendation

72. Cohen D, Melamed S, Millman A, et al:: Cyclic GMP-AMP signalling protects bacteria against viral infection. Nature. 2019; 574(7780): 691-5.

PubMed Abstract | Publisher Full Text | Faculty Opinions Recommendation

73. Severin GB, Ramliden MS, Hawver LA, et al:: Direct activation of a phospholipase by cyclic GMP-AMP in EI Tor Vibrio cholerae. Proc Natl Acad Sci U S A. 2018; 115(26): E6048-E6055

PubMed Abstract | Publisher Full Text | Free Full Text

74. Niewoehner O, Garcia-Doval C, Rostøl JT, et al:: Type III CRISPR-Cas systems produce cyclic oligoadenylate second messengers. Nature. 2017; 548(7669): 543-8.

PubMed Abstract | Publisher Full Text

75. Kazlauskiene M, Kostiuk G, Venclovas Č, et al.: A cyclic oligonucleotide signaling pathway in type III CRISPR-Cas systems. Science. 2017; 357(6351): 605-9.

PubMed Abstract | Publisher Full Text | Faculty Opinions Recommendation

76. Lowey B, Whiteley AT, Keszei AFA, et al:: CBASS Immunity Uses CARFRelated Effectors to Sense 3'-5'- and 2'-5'-Linked Cyclic Oligonucleotide Signals and Protect Bacteria from Phage Infection. Cell. 2020; 182(1): 38-49.e17.

PubMed Abstract | Publisher Full Text | Free Full Text |

Faculty Opinions Recommendation

77. Lau RK, Ye Q, Birkholz EA, et al: Structure and Mechanism of a Cyclic Trinucleotide-Activated Bacterial Endonuclease Mediating Bacteriophage Immunity. Mol Cell. 2020; 77(4): 723-733.e6. PubMed Abstract | Publisher Full Text | Free Full Text Faculty Opinions Recommendation

78. Morehouse BR, Govande AA, Millman A, et al.: STING cyclic dinucleotide sensing originated in bacteria. Nature. 2020; 586(7829): 429-33. PubMed Abstract | Publisher Full Text | Free Full Text |

Faculty Opinions Recommendation 
79. Burroughs AM, Aravind L: Identification of Uncharacterized Components of Prokaryotic Immune Systems and Their Diverse Eukaryotic Reformulations. J Bacteriol. 2020; 202(24): e00365-20.

PubMed Abstract | Publisher Full Text | Free Full Text

80. Tong L: How to diSARM the executioner of axon degeneration. Nat Struct Mol Biol. 2021; 28(1): 10-2.

PubMed Abstract | Publisher Full Text

81. Zhang C, Shang G, Gui X, et al:: Structural basis of STING binding with and phosphorylation by TBK1. Nature. 2019; 567(7748): 394-8. PubMed Abstract | Publisher Full Text | Free Full Text | Faculty Opinions Recommendation

82. Swarts DC, Makarova $\mathrm{K}, \mathrm{Wang} \mathrm{Y}$, et al:: The evolutionary journey of Argonaute proteins. Nat Struct Mol Biol. 2014; 21(9): 743-53.

PubMed Abstract | Publisher Full Text | Free Full Tex
83. Ye Q, Lau RK, Mathews IT, et al.: HORMA Domain Proteins and a Trip13like ATPase Regulate Bacterial cGAS-like Enzymes to Mediate Bacteriophage Immunity. Mol Cell. 2020; 77(4): 709-722.e7.

PubMed Abstract | Publisher Full Text | Free Full Text |

Faculty Opinions Recommendation

84. McFarland AP, Luo S, Ahmed-Qadri F, et al: Sensing of Bacterial Cyclic Dinucleotides by the Oxidoreductase RECON Promotes NF- B Activation and Shapes a Proinflammatory Antibacterial State. Immunity. 2017; 46(3): 433-45. PubMed Abstract | Publisher Full Text | Free Full Text | Faculty Opinions Recommendation

85. McFarland AP, Burke TP, Carletti AA, et al:: RECON-Dependent Inflammation in Hepatocytes Enhances Listeria monocytogenes Cell-to-Cell Spread. mBio. 2018; 9(3): e00526-18.

PubMed Abstract | Publisher Full Text | Free Full Text 